\title{
Pengaruh Penggunaan Metode Eksperiman, Pembelajaran Konvensional Dan Motivasi Belajar Terhadap Prestasi Belajar Digital Taruna DIII TNU 9A dan TNU 9B Akademi Teknik Dan Keselamatan Penerbangan Surabaya
}

\author{
Moch. Rifai \\ Akademi Teknik dan Keselamatan Penerbangan Surabaya \\ Jl Jemur Andayani 1/73 Surabaya 60236
}

\begin{abstract}
To give clearness in this research, it is required to formula the problems review of realeted literatures are: 1) is there a learning achievement difference in Digital Technique among Experimental Methodes tudents and Conventional Learning studenst? 2). Is there a learning achievment different in Digital Technique between high and low learning motivation students? 3). Is there an interaction among Experimental Methode, Coventional Learning and learning motivation in influencing Digital Technique learning achievment class DIII TNU 9A and DIII TNU 9B ATKP Surabaya.

Population is class DIII TNU 9A and DIII TNU 9B ATKP Surabaya. The class is taken with one semester experience in First Semester, so students do not find standard study pattern and then give straight assessment to certain Learning. Sample of students is one class TNU 9A 20 students use Experimental Methode and one class TNU 9B 20 cadets use Conventional Learning system each randomly. Selected and depend on teacher's readiness to accept the process.

This research uses quantitative approach in experimental frame.the group is divided in two, experimental and control group. Experimental group uses Experimental Methode, while control group use conventional learning (direct teaching ). In this research, the compared learning method is Experimental Method, Conventional learning method, and motivation, which is grouped into two : high and low motivation, so research design is questionnaire and test, while data analysis uses two ways ANAVA and SPSS.

From hypothesis I, Ha is accepted and Ho is rejekted, hypothesis says " there is learning achivment difference in Digital Technique among Experimental Method students and Conventional Learning students. From hypothesis 2, Ha is accepted and Ho is rejected. Thus, there is learning achivement difference in Digital Technique among high motivation students and low motivation students. From hypotesis 3, Ha is accepted and Ho is rejected, hypothesis says " there is interaction among Experimental Method, conventional learning and learning Motivation in influencing Digital Techniquel earning achievment class DIII TNU 9A and DIII TNU 9B ATKP Surabaya.
\end{abstract}

Keywords: Experimental Method, Conventional Learning, Learning Motivation, learning Achievement.

\section{LATAR BELAKANG}

Teknik penyajian pelajaran adalah suatu pengetahuan tentang cara-cara mengajar yang dipergunakan oleh guru atau instruktur. Pengertian lain ialah sebagai teknik penyajian yang dikuasai guru untuk mengajar atau menyajikan bahan pelajaran kepada siswa di dalam kelas, agar pelajaran tersebut dapat ditangkap, dipahami dan digunakan oleh siswa dengan baik. Salah satu teknik penyajian pelajaran yang digunakan dalam penelitian ini adalah teknik penyajian pelajaran eksperimen atau disebut juga dengan metode eksperimen. 
Menurut Schoenherr (1996) yang dikutip oleh Palendeng (2003:81) metode eksperimen adalah metode yang sesuai untuk pembelajaran sains, karena metode eksprimen mampu memberikan kondisi belajar yang dapat mengembangkan kemampuan berfikir dan kreativitas secara optimal. Siswa diberi kesempatan untuk menyusun sendiri konsep-konsep dalam struktur kognitifnya, selanjutnya dapat diaplikasikan dalam kehidupannya. Metode Eksperimen menurut Al-farisi (2005:2) adalah metode yang bertitik tolak dari suatu masalah yang hendak dipecahkan dan dalam prosedur kerjanya berpegang pada prinsip metode ilmiah.

Menurut Joseph Mbulu, 2001:58 Metode eksperimen adalah cara penyajian bahan pelajaran di mana siswa melakukan eksperimen (percobaan) dengan mengalami dan membuktikan sendiri sesuatu yang dipelajari. Dalam proses belajar mengajar dengan metode eksperimen, siswa diberi pengalaman untuk mengalami sendiri tentang suatu objek, menganalisis, membuktikan, dan menarik kesimpulan tentang suatu objek keadaan. Dengan demikian siswa dituntut untuk mengalami sendiri, mencari suatu kebenaran, mencari suatu data baru yang diperlukannya, mengolah sendiri, membuktikan suatu dalil atau hukum dan menarik kesimpulan.

Perbedaan utama antara metode konvensional dan metode eksperimen perilaku taruna dan dosen. Pada metode konvensional, peran dosen aktif dan taruna pasif, sedangkan pada metode eksperimen taruna aktif, dosen cenderung pasif sebagai fasilitator.

Untuk mengetahui pengaruh penggunaan sistem pembelajaran menggunakan metode eksperimen pada taruna ATKP surabaya, penulis mengambil sample taruna DIII TNU 9A dan Taruna DIII TNU 9B pada mata kuliah teknik digital. Masing - masing uji sample diberi perlakuan yang sama.

\section{METODE}

Penelitian ini menggunakan pendekatan kuantitatif dengan rancangan eksperimental. Penelitian ini berusaha untuk mencari dan menguji pengaruh satu variabel atau lebih terhadap variabel yang lain. Variabel yang memberi pengaruh disebut dengan variabel bebas (independent variables) dan variabel yang dipengaruhi disebut sebagai variabel terikat (dependent variables) (Sukmadinata, 2006:58). Variabel bebas dalam penelitian ini adalah pembelajaran Teknik Digital, baik yang diselenggarakan dengan metode eksperimen, maupun dengan menggunakan metode konvensional di dalam kelas. Sedangkan variabel terikat adalah hasil belajar taruna dalam mata kuliah Teknik Digital.

Dalam penelitian ini metode pembelajaran yang dibandingkan adalah metode eksperimen serta motivasi, yang dibedakan menjadi dua yaitu motivasi tinggi dan motivasi rendah, terhadap metode pembelajaran konvensional (pengajaran langsung) sehingga desain penelitiannya adalah rancangan faktoral 2x2 ( Suryasubrata, 1991:56)

Penelitian kuantitatif dipandang sebagai sesuatu yang bersifat konfirmasi dan deduktif, sedangkan penelitian kualitatif bersifat eksploratoris dan induktif. Bersifat konfirmasi disebabkan karena metode penelitian kuantitatif ini bersifat menguji hipotesis dari suatu teori yang telah ada. Penelitian bersifat mengkonfirmasi antara teori dengan kenyataan yang ada dengan mendasarkan pada data ilmiah baik dalam bentuk angka. Penarikan kesimpulan bersifat deduktif yaitu dari sesuatu yang bersifat umum ke sesuatu yang bersifat khusus. Hal ini berangkat dari teori-teori yang membangunnya.

Untuk mengetahui pengaruh penerapan metode eksperimen terhadap prestasi belajar pada mata kuliah Teknik Digital, dilaksanakan tes pada kelompok eksperimen dan kelompok kontrol. Tes dilaksanakan serentak pada masing-masing kelompok setelah perkuliahan dengan metode eksperimen dimulai. Tes ini bertujuan untuk mengetahui kemampuan awal para taruna di setiap 
kelompok dan mengukur kemampuan mereka dalam mata kuliah Teknik Digital. Tes diberikan setelah perkuliahan berlangsung selama beberapa kali pertemuan.

Sesuai dengan hubungan antar variabel yang disebut pada bab terdahulu, maka penelitiannya dapat digambarkan dalam diagram sebagai berikut :

\section{Keterangan :}

\begin{tabular}{|r|r|r|}
\hline $\mathrm{X}_{\mathrm{A}}$ & $\mathrm{X}_{1}$ & $\mathrm{X}_{2}$ \\
\hline $\mathrm{A}_{1}$ & $\mathrm{Y} 1$ & $\mathrm{Y} 2$ \\
\hline $\mathrm{A}_{2}$ & $\mathrm{Y} 3$ & $\mathrm{Y} 4$ \\
\hline
\end{tabular}

A $\quad=$ Metode mengajar, yang terdiri

$\mathrm{A}_{1} \quad=$ Metode Eksperimen

$\mathrm{A}_{2} \quad=$ Metode Konvensional

$\mathrm{X}=$ Motivasi belajar, terdiri dari

$\mathrm{X}_{1}=$ Motivasi belajar tinggi

$\mathrm{X}_{2}=$ Motivasi belajar tendah

$\mathrm{Y} 1=$ Prestasi belajar yang diajar dengan $\mathrm{A}_{1}$ dan motivasi $\mathrm{X}_{1}$

$\mathrm{Y} 2=$ Prestasi belajar yang diajar dengan $\mathrm{A}_{1}$ dan motivasi $\mathrm{X}_{2}$

$\mathrm{Y} 3=$ Prestasi belajar yang diajar dengan $\mathrm{A}_{2}$ dan motivasi $\mathrm{X}_{1}$

$\mathrm{Y} 4=$ Prestasi belajar yang diajar dengan $\mathrm{A}_{2}$ dan motivasi $\mathrm{X}_{2}$

\section{A. Populasi dan Sampel}

Populasi dari penelitian ini adalah seluruh taruna ATKP Surabaya semester 2 Program Studi Teknik Navigasi Udara angkatan 9A dan 9B. Pada Prodi Teknik Navigasi Udara Angkatan 9A terdapat satu kelas taruna semester 2 dengan jumlah taruna 29 orang. Sedangkan pada Prodi Teknik Navigasi Udara Angkatan 9B terdapat satu kelas taruna semester 2 dengan jumlah taruna 30 orang.

\section{Pengumpulan Data.}

\section{a. Jenis Data}

1.) Data prestasi belajar Teknik Digital adalah data interval

2 ) Data motivasi belajar adalah data ordinal

b. Teknik Pengumpulan Data

Untuk mengolah data yang diperlukan dalam penelitian ini menggunakan teknik sebagi berikut :

1. Metode Angket.

Untuk lebih jelasnya dibuat kisi-kisi instrumen angket motivasi sebagai berikut :

\begin{tabular}{|l|l|c|c|}
\hline No & \multicolumn{1}{|c|}{ Indikator } & No. Soal & Jumlah \\
\hline 1. & Ketekunan belajar & $1,3,5,7,9,11$ & 6 \\
\hline 2. & Ketekunan dalam meningkatkan status & $2,6,8$ & 3 \\
\hline 3. & Bersaing & $4,10,14$ & 3 \\
\hline 4. & Menghargai karya orang lain & 12,17 & 2 \\
\hline 5 & Kreatifitas & $13,15.18$ & 3 \\
\hline
\end{tabular}


2. Metode Test

\begin{tabular}{|c|c|c|c|}
\hline 6 & Cita-cita & $16,19,20$ & 3 \\
\hline \multicolumn{3}{|c|}{ Jumlah } & $\mathbf{2 0}$ \\
\hline
\end{tabular}

\section{Teknis Analisis Data}

1) Uji persyaratan.

Dalam penelitian ini teknis analisis yang digunakan adalah anava dua jalur. Untuk itu sebelumnya dilakukan uji hipotesis terlebih dahulu dilakukan persyaratan, adapun uji persyaratan sebagai berikut :

a) Uji Normalitas.

Pengujian normalitas dilakukan dengan uji Lilliefors yang diringkas pada tabel berikut ini.

Tabel 4.9 Rangkuman hasil uji normalitas sampel dengan uji Lilliefors pada taraf signifikansi $\alpha=\mathbf{0 , 0 5}$.

\begin{tabular}{|c|c|c|c|c|}
\hline Variabel & Lo & Lt & $p_{\text {value }}$ & Keterangan \\
\hline Strategi Pembelajaran & 0.077 & 0,140 & 0.200 & Normal \\
\hline Motivasi & 0.119 & 0,140 & 0.162 & Normal \\
\hline Prestasi Belajar & 0.121 & 0,140 & 0.141 & Normal \\
\hline
\end{tabular}

Dari tabel 4.9 tersebut di atas untuk semua kelompok dapat dilihat harga Lo lebih kecil daripada harga Lt, dan nilai $p_{\text {value }}$ untuk seluruh variabel yang lebih besar dari taraf signifikan 0,05. Dengan demikian dapat disimpulkan bahwa variabel-variabel pada penelitian ini berasal dari populasi yang berdistribusi normal.

\subsection{Uji Homogenitas.}

Pengujian homogenitas variansi populasi dilakukan dengan Uji Levene. Dengan uji homogenitas dapat diketahui kesamaan varian variabel terikat (prestasi belajar) berdasarkan setiap variansi skor variabel bebas (strategi pembelajaran dan Motivasi). Ringkasan uji homogenitas tersebut disajikan pada tabel berikut ini

Tabel 4.10 Ringkasan Uji Homogenitas dengan Uji Levene pada taraf signifikansi $\alpha=$ $\mathbf{0 , 0 5}$

\begin{tabular}{|c|l|c|c|c|c|}
\hline \multirow{2}{*}{ No } & \multirow{2}{*}{ Variabel } & \multicolumn{2}{|c|}{ Nilai } & \multirow{2}{*}{$p_{\text {value }}$} & Keterangan \\
\cline { 3 - 4 } & & $F_{\text {hitung }}$ & $F_{\text {tabel }}$ & & \\
\hline 1 & Metode Belajar & 2,101 & 4,08 & 0,069 & Homogen \\
2 & Motivasi & 1,302 & 4,08 & 0,309 & Homogen \\
\hline
\end{tabular}

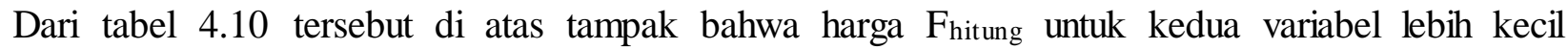
daripada harga $\mathrm{F}_{\text {tabel, }}$, dan nilai $p_{\text {value }}$ untuk seluruh variabel yang lebih besar dari taraf signifikan 0,05. Dengan demikian dapat disimpulkan bahwa data berupa skor prestasi belajar fisika elektronika dari setiap kelompok memiliki varians populasi yang homogen. 


\section{HASIL PENELITIAN}

Hasil Uji Hipotesis.

Sebelum dilakukan pengujian hipotesis tertulis terlebih dahulu dipaparkan diskripsi variabel sebagai berikut :

a. Pengujian Hipotesis pertama

Dari deskripsi data diperoleh gambaran hasil rata-rata prestasi belajar teknik digital antara kelompok taruna yang diberikan metode eksperimen dan yang diberikan metode Konvensional. Untuk taruna yang diberikan metode eksperimen diperoleh nilai rata-rata sebesar 79,25, sedangkan yang diberikan strategi Konvensional sebesar 72,13.

Tabel berikut menunjukkan perbedaan secara deskriptif dari kedua kelompok tersebut.

Tabel 4.11 Perbandingan Prestasi Belajar dengan metode Eksperimen dan Konvensional

\begin{tabular}{|c|c|c|c|c|}
\hline Metode & Rata-Rata & Nilai Minimum & Nilai Maksimum & Modus \\
\hline Eksperimen & 79,25 & 62,50 & 90,00 & 80,00 \\
\hline Konvensional & 72,13 & 57,50 & 82,50 & 72,50 \\
\hline
\end{tabular}

berikut ini

Dari hasil pengujian Uji-t dari kedua kelompok penelitian diperoleh hasil seperti tabel

Tabel 4.12 Analisis Uji-t Hipotesis I

\begin{tabular}{|c|c|c|c|}
\hline thitung & t tabel & Df & Besarnya pengaruh \\
\hline 3,083 & 1,68 & 38 & 0,665 \\
\hline
\end{tabular}

Dari tabel 4.12 tersebut diperoleh nilai t observasi atau t-hitung sebesar 3,083 di mana pada taraf $0,05(\mathrm{df}=38)$ nilai $\mathrm{t}$ tabel adalah 1,68 . Dengan membandingkan nilai $\mathrm{t}$ tersebut maka dapat kita lihat $t_{h}=3,083$ lebih besar dari $t_{t}=1,68$ pada taraf $\alpha=5 \%$, sehingga ini menunjukkan Ho ditolak yang berarti ada perbedaan yang signifikan prestasi belajar taruna yang diberikan metode eksperimen dengan yang diberikan metode Konvensional pada teknik digital. Dengan kata lain, bahwa prestasi belajar taruna yang menggunakan metode eksperimen lebih tinggi dibandingkan dengan taruna yang diberikan metode konvensional pada teknik digital untuk taruna semester 2 .

Hasil perhitungan dengan regresi sederhana juga menunjukkan bahwa besarnya pengaruh metode pembelajaran terhadap prestasi belajar sebesar 0,665. Hal ini berarti sebesar 66,5\% peningkatan prestasi belajar dipengaruhi oleh adanya metode pembelajaran.

b. Pengujian Hipotesis kedua.

Dari deskripsi data diperoleh gambaran hasil rata-rata prestasi belajar teknik digital antara kelompok taruna yang memiliki motivasi tinggi dan yang memiliki motivasi rendah. Untuk taruna yang memiliki motivasi tinggi diperoleh nilai rata-rata sebesar 79,00, sedangkan yang memiliki motivasi rendah diperoleh nilai rata-rata sebesar 72,38.

Tabel berikut menunjukkan perbedaan secara deskriptif dari kedua kelompok tersebut.

Tabel 4.13 Perbandingan Prestasi Belajar Motivasi Tinggi dan Rendah

\begin{tabular}{|c|c|c|c|c|}
\hline Motivasi & Rata-Rata & Nilai Minimum & Nilai Maksimum & Modus \\
\hline Tinggi & 79,00 & 70,00 & 90,00 & 75,00 \\
\hline Rendah & 72,38 & 57,50 & 87,50 & 62,50 \\
\hline
\end{tabular}

Dari hasil pengujian Uji-t dari kedua kelompok penelitian diperoleh hasil seperti tabel berikut ini

Tabel 4.14 Analisis Uji-t Hipotesis II

\begin{tabular}{|c|c|c|c|}
\hline$t_{\text {hitung }}$ & $\mathrm{t}_{\text {tabel }}$ & Df & Besarnya pengaruh \\
\hline 2,819 & 1,68 & 38 & 0,731 \\
\hline
\end{tabular}


Dari tabel tersebut diperoleh nilai t observasi atau t-hitung sebesar 2,819 dimana pada taraf 0,05 ( $\mathrm{df}=38$ ) nilai $\mathrm{t}$ tabel adalah 1,68. Dengan membandingkan nilai t tersebut maka dapat kita lihat $t_{\mathrm{h}}=2,819$ lebih besar dari $\mathrm{t}_{\mathrm{t}}=1,68$ pada taraf $\alpha=5 \%$, sehingga ini menunjukkan Ho ditolak yang berarti ada perbedaan yang signifikan prestasi belajar taruna yang memiliki motivasi tinggi dengan taruna yang memiliki taruna rendah pada teknik digital. Dengan kata lain, bahwa prestasi belajar taruna yang memiliki motivasi tinggi lebih tinggi dibandingkan dengan taruna yang memiliki motivasi rendah pada teknik digital untuk taruna Prodi TNU semester 2.

Hasil perhitungan dengan regresi sederhana juga menunjukkan bahwa besarnya pengaruh tingkat motivasi terhadap prestasi belajar sebesar 0,731. Hal ini berarti sebesar 73,1\% peningkatan prestasi belajar dipengaruhi oleh adanya tingkat motivasi taruna.

c. Pengujian Hipotesis ketiga.

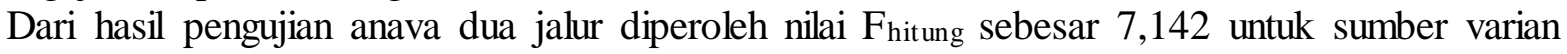
antar kelompok. Dengan membandingkan nilai $\mathrm{F}$ tersebut maka dapat kita lihat $\mathrm{F}_{\mathrm{h}}=7,142$ lebih besar dari $\mathrm{F}_{\mathrm{t}}=2,85$ pada tingkat signifikan $\alpha=5 \%$, sehingga ini menunjukkan $\mathrm{H}_{\mathrm{o}}$ ditolak yang berarti ada interaksi antara strategi pembelajaran dan tingkat motivasi secara bersama-sama terhadap prestasi belajar pada teknik digital untuk taruna Prodi TNU Semester 2.

Tabel di bawah ini menunjukkan hasil yang diperoleh dari analisis perhitungan anava dua jalur

Tabel 4.15 Tabel ANAVA Hipotesis III

\begin{tabular}{|c|c|c|c|c|}
\hline Sumber Data & JK & F $_{\text {hit }}$ & $\mathrm{F}_{\mathrm{T}}(0.05)$ & Besarnya Pengaruh \\
\hline Metode dan Motivasi & 946,719 & 7,142 & 2,85 & 0,796 \\
\hline
\end{tabular}

Dari hasil perhitungan regresi berganda juga didapatkan nilai besarnya pengaruh sebesar 0,796, yang artinya sebanyak 79,6\% interaksi antara strategi pembelajaran dan motivasi berpengaruh terhadap prestasi belajar pada teknik digital untuk taruna Prodi TNU Semester 2.

\section{PEMBAHASAN}

Sesuai hasil pengujian hipotesis pertama tampak bahwa metode eksperimen memberikan prestasi belajar teknik digital yang lebih tinggi dibanding dengan pembelajaran konvensional. Ini menunjukkan bahwa metode eksperimen dan strategi konvensonal memiliki perbedaan pengaruh apabila dilaksanakan dalam pengajaran mata kuliah teknik digital di Akademi Teknik dan Keselamatan Penerbangan Surabaya. Dengan demikian metode eksperimen memiliki keunggulan tersendiri sesuai situasi dan kondisi di mana strategi tersebut diterapkan.

Pada dasarnya metode eksperimen dan strategi konvensional adalah dua model yang berbeda, bila dilihat dari segi prosedur dan pelaksanaannya. Dalam metode eksperimen, taruna diberi kesempatan untuk mengembangkan dan mengungkapkan sendiri setiap konsep yang sudah ada dalam struktur kognitifnya dalam arti taruna dituntut secara aktif untuk mengaitkan konsepkonsep yang sudah ada dalam struktur kognitifnya dengan konsep-konsep baru.

Sebaliknya pada strategi konvensional dosen dituntut lebih aktif, dalam hal ini dosen adalah pihak yang dapat dikatakan dominan melalui aktivitasnya dalam memberikan pengetahuan atau 
informasi. Karena itu taruna hanya menjadi penerima informasi yang dianggap memiliki daya serap yang sama tanpa mempertimbangkan kemampuan dan kondisi taruna yang bersangkutan.

Hasil pengujian hipotesis kedua menunjukkan bahwa taruna yang memiliki tingkat motivasi tinggi mempunyai prestasi belajar teknik digital lebih baik dibanding dengan taruna yang memiliki tingkat motivasi rendah.

Selanjutnya hasil pengujian hipotesis ketiga menunjukkan adanya interaksi antara metode pembelajaran dan motivasi terhadap prestasi belajar teknik digital. Dengan demikian dapat dikatakan bahwa efektivitas dari metode pembelajaran yang digunakan dalam teknik digital juga tergantung pada tingkat motivasi yang dimiliki oleh taruna. Di mana, metode eksperimen lebih sesuai jika diberikan kepada taruna yang memiliki tingkat motivasi tinggi. Hal ini dibuktikan dengan tidak adanya perbedaan antara pemberian metode eksperimen dengan motivasi rendah dibandingkan dengan pemberian strategi konvensional dengan motivasi tinggi.

Kesesuaian penggunaan metode eksperimen terhadap taruna yang memiliki motivasi tinggi disebabkan karena pada hakikatnya untuk strategi ini dibutuhkan potensi kreatif. Bagi taruna yang memiliki motivasi tinggi penyajian prmbelajaran melalui metode eksperimen dapat merangsang keluarnya ide-ide untuk menyusun suatu struktur konsep yang bermakna. Hal ini disebabkan karena tingkat motivasi bersifat konstruktif, artinya tingkat motivasi dapat menentukan terbentuknya karakter struktur kognitif seseorang.

\section{SIMPULAN DAN SARAN}

Pada hal ini diuraikan secara berturut-turut kesimpulan hasil penelitian dan saran-saran, baik yang berhubungan dengan penggunaan hasil penelitian maupun untuk penelitian lanjutan.

\section{A. Simpulan}

Berdasarkan hasil pengujian hipotesis maka simpulan penelitian adalah sebagai berikut:

1) Metode eksperimen memberikan prestasi belajar teknik digital yang lebih baik dibanding dengan strategi konvensional.

2) Motivasi tinggi memberikan prestasi belajar teknik digital yang lebih baik dibanding dengan motivasi rendah. Namun demikian tidak terdapat perbedaan prestasi belajar teknik digital antara kelompok yang diberikan metode eksperimen - motivasi rendah dengan strategi konvensional-motivasi tinggi

3) Terdapat interaksi antara metode pembelajaran dan motivasi terhadap prestasi belajar teknik digital.

\section{B. Saran}

Hasil penelitian ini diharapkan akan memberi masukan pada dosen khususnya Dosen teknik digital di ATKP Surabaya untuk menentukan kesesuaian metode pembelajaran yang digunakan.

Sebagaimana diketahui metode eksperimen dan konvensional ternyata memberikan perbedaan terhadap prestasi belajar teknik digital, namun hal itu juga tergantung dari motivasi taruna. Oleh karena itu, apabila informasi tentang tingkat motivasi taruna tidak diketahui maka dapat saja kedua metode tersebut digunakan melalui pertimbangan tertentu seperti tujuan belajar yang akan dicapai, kemampuan dosen yang bersangkutan terhadap strategi tersebut, maupun topik bahasan yang akan disajikan.

\section{DAFTAR PUSTAKA}

Arikunto, Suharsimi.2000, Managemen Penelitian. Jakarta : PT Asdi Mahasatya. 
.2002, Prosedur Penelitian Suatu Pendekatan Praktis. Jakarta: Rineka Cipta

Budiarjo, Lily 2000, Metode Instruksional, Dala Cristina S .mangindaan. Bagian Tiga. Program Applied Approach. Jakarta: PAU- UI

Brown, M. (2005). Learning Space, dalam Educating the Net Generation. Washington: Educause.

Departemen Pendidikan dan Kebudayaan (2003). Kamus Besar Bahasa Indonesia. Jakarta: Balai Pustaka.

Fraenkel, J.R., Wallen, N.E. (2007). How to Design and Evaluate Research in Education 6th Edition. New York: Mc Graw Hill.

Herman J Waluyo (1995), Uji analisa linkert. Bandung, Aksara

Kardi, Soeparman, dan Muhammad Nur. 2000, Pengajaran Langsung. Surabaya : Unesa University Press

. 2000, Berbagai Pendekatan Dalam Proses Belajar mengajar. Jakarta:

Bumi Aksara

Oblinger, D.G, dan Oblinger, J.L. (Eds) (2005). Educating the Net Generation. Washington: Educause.

Porter, L. R., (2004). Developing an Online Curriculum: Technologies and Techniques. Hershey: Information Science Publishing.

Ramaley, J., dan Zea, L. (2005). The Real Versus the Possible: Closing the Gaps in Engagement and Learning, dalam Educating the Net Generation. Washington: Educause.

Ruswandi. (2008). Manajemen Kurikulum, Jakarta: Rajawali Press. Sanjaya, W. (2008). Kurikulum dan Pembelajaran, Jakarta: Kencana.

Sanjaya, W. (2008). Perencanaan dan Desain Sistem Pembelajaran, Jakarta: Kencana Prenada Media Group.

Sudrajat, A. (2008). Teori-teori Belajar. [online]. Tersedia: http// /akhmadsudrajat.wordpress.com/2008/02/02/teori-teori-belajar/index.html. [18 Jan 2012]

Sadirman. 2005, Interaksi dan Motivasi Belajar mengajar, Jakarta: Bina Aksara

Sudjana, Nana. 2005, Penelitian Hasil Proses Belajar Mengajar . Bandung: Remaja Rosdakarya.

Suryabrata, Sumadi. 2001. Psykologi Pembelajaran. Jakarta: Grafindo Persada. , 2002. Metodologi Penelitian. Jakarta : Grafindo Persada.

Sukmadinata, N. S. (2006). Metode Penelitian Pendidikan. Bandung: Remaja Rosdakarya.

Thursan Hakim (2000). Metode Penelitian Pendidikan Bandung: Remaja Rosdakarya. 